\title{
The Development of Chinese Buddhist Music and Its Interaction with Folk Music
}

\author{
Li Yan \\ School of Humanities \\ China University of Political Science and Law \\ Beijing, China 100088
}

\begin{abstract}
Buddhist music, as foreign religious music for China, is deeply influenced by the regional and spontaneous characteristics of Chinese folk music in the process of localization, forming different schools with local music characteristics. At the same time, Buddhist music and Chinese folk music continue to integrate, enriching the Chinese folk music content and evolved into a variety of artistic carrier.
\end{abstract} fusion

Keywords-Buddhist music; folk music; local; impromptu;

\section{INTRODUCTION}

Chinese Buddhist music, by rendering and strengthening the atmosphere of religious rituals, attracted popular and spread religious doctrine, and gradually developed into an important part of Chinese religious music.

\section{The DEVELopMent OF CHINESE BUdDHIST MusiC}

The development of Chinese Buddhist music has gone through four stages:

- From the beginning to the end of Han Dynasty, Buddhist music was completely "Westernized". This period of Chinese Buddhist music basically mimicked Indian Buddhist music.

- From Eastern Jin (东晋) to Qi Liang (齐梁) dynasty, Buddhist music was gradually influenced by the missionary music, presenting the trend of diversity.

- During Sui (隋) and Tang (唐) Dynasties, Buddhist music appeared prosperity and stereotypes with the prosperity of Buddhism;

- From Song (宋) and Yuan (元) dynasties to modern times, Buddhism gradually integrated with Confucianism and Taoism. Buddhist music presented the development trend of folklore, and gradually went into the daily life of ordinary people. With the decline of Buddhism, Buddhist music and folk music continue to integrate. Buddhist music was widely absorbed into folk music, performing the trend of popularization and decay.

Buddhism spreading into China from Eastern Han Dynasty, from India through the Silk Road in Central Asia into the mainland was one of the routes. At the same time
Buddhist music with the Western Regions and Indian local characteristics also came. During Northern and Southern Dynasties, Buddhist music gradually integrated with court music and folk music. "Records of Luoyang Gala" (洛阳伽蓝 记) preserved the Northern Wei Dynasty (北魏) Buddhist music and dance style, describing the Buddhist temple of major religious activities through music: "Buddhist music, the immortal world, a hundred tattoo, parallel show". There was also King music Temple which was set up for female. "Songs around the beam, dance sleeve gradually turning, voice of music was loud and clear, all of music made people spiritually harmonious and wonderful. In Sui Dynasty, court music contained the XiLiang music (西凉乐), Tianzhu music (天䇥乐) and other Buddhist music. In Tang Dynasty, Buddhist music was widely prevalent in social life, Buddhist music going into popular country in popular ways. In Tang Dynasty, court indulged in Buddhist music, and ordinary people put religious activities of Buddhist temple monastery as the most important local entertainment venues. In Tang Dynasty, regardless of monasteries, palace, music contained folk music and Buddhist music, has reached its peak. The popularization of the Pure Land of the Buddhist schools in Tang Dynasty also created an unprecedented good condition for the widespread of Buddhist music and the extensive use of music in religious activities. Tang's court music inherited the Sui tradition, in the Buddhist festival "to do the Buddha dance, such as the Buddha was born." In Tang Dynasty monastery also had a special theater, through the dance, vulgar, acrobatics and other music activities to attract and publicize the people of Buddhism. A large number of Buddhist monasteries set religious, entertainment, commercial functions, as a place for folk worship, entertainment and merchandise exchange. At the beginning of the Northern Song Dynasty, because of the mixed men and women in religious activities, the government banned the monasticism in monastery. So the monks went to the folk residence combined with folk music to explain the Buddhist scriptures and teachings. Buddhist music's religion gradually faded. Ming Dynasty collected and sorted out the popular Buddhist music tunes since Tang and Song, and compiled into a book in order to issue to all the country. This music compilation farthest reaches Vietnam and Myanmar. Since Ming Dynasty, the "Baojuan" (宝卷) that is a kind of record of folk religion's doctrine, began to prevail with the rapid rise of Luo-jiao (罗教) and other new folk religion. 
"Baojuan" recorded the popularization and folklore Buddhist doctrine. Buddhist music and folk music in-depth integration of local characteristics was more prominent. After the Republic of China, with the decline of Buddhism, Buddhist music has been more in the way of folk music.

\section{THE IMPACT OF CHINESE FOLK MUSIC ON BUDDHIST MUSIC}

Chinese folk music is a folk genre that is popular in folk, and is popular in folk songs such as songs, dances, instrumental music, opera and rap. It is foundation of traditional music such as Chinese court music, scholar music and religious music. Buddhist music development process and history by the impact of Chinese folk music, is the essence of Chinese traditional music and an important traditional cultural heritage.

Buddhist music can be divided into three categories according to the content: (1) Zen music (禅宗音乐) as the representative of the authentic Buddhist music; (2) religious music used by informal monks; (3) Quasi-buddhist music used by popular Buddhist. Zen is a combination of Chinese cultural traditions and Buddhism, which produce a high degree of localization. Zen music is also a combination of Buddhist and local folk music. Religious elements weakened and secular elements increased in adapted music. So, Zen music is a typical secular Buddhist music or the religious secular folk music. The Buddhist music used by the believers, whose melodies, tunes, interval and content were deeply influenced by folk music in the area of believers, interpreting the basic teachings and contents of Buddhism with local folk music. All of above, Buddhist music tends to be in the content of Buddhism, but it is more in the form of music to absorb the form of local folk music. The process of the development of Buddhist music in China is deeply influenced by Chinese folk music and gradually integrated with folk music.

\section{A. Chinese Folk Music Adapted to Buddhist Music When Buddhist Music Has just been Introduced into China}

Indian Buddhists are using India's tone “Bai" (呗) sound praise the Buddha, rich melody, rhyme ups, thus, the listener is appealing and attractive. After the Buddhist music began to spread to China, "Bai" of Indian Buddhist music evolved into "read", "Buddhist chanting" into "song praise". In Chinese and Indian languages, due to different voices, Indian Buddhist music tunes was very difficult to spread in China for a long time. In order to promote the Dharma, Chinese monks gradually use Chinese folk music to adapt to foreign Buddhist music, or in accordance with local folk music to create new Buddhist music, such as "Mieshouxiang" (灭受 想曲） is one of the Uygur's "twelve Mukam"（十二木卡姆）. In Tang Dynasty, Buddhism in the process of missionary, used "by painting" (经变画) and "Sujiang" (俗讲) way to solve the classics profound problem of Buddhist doctrine. In the beginning in the Tang Dynasty, "Sujiang" was a kind of communication, which was talking and singing at the same time alternately. There were some advantages of this communication: (a) low cost of missionary; (b) a wide range of religious propaganda; (c) meeting the level of popular culture and education; (d) to be accepted by the public easily,etc. "Vulgar" profoundly influenced later secular music later secular music, Popular literature and other religions.

\section{B. The Regional Characteristics of Chinese Folk Music Deeply Influenced on Buddhist Music}

It was the reasons formed different geographical culture that concerned China's vast territory, diverse terrain and in the great nation, as the process of cultural development and traditions is different, the regional folk music in the composition of the elements of the music is different. The discourse differences in local dialects lead to differences in folk melodies in different places. In addition, the differences between the public characters also led to the existence of emotional differences in folk music. In general, the northern folk music more use of seven sound scale, melody interval, melody movement more jump, melody line angular, full of narrative features. Southern folk music more use five sound scale, melody interval is smaller, melodic movement multilevel advance, melody line twists and turns, full of lyrical features.

Buddhist music that influenced by the local geographical feature, the same music theme in different regions have differences such as language, personality and music preferences. Therefore, the differences between north and south folk music are also reflected in Buddhist music. In the Northern and Southern Dynasties, there are gradually three types of Buddhist music on the basis of the different regions: (a) the Buddhist music of the area of Central Plains, represented by Luoyang district; (b) the Buddhist music of Jiangnan area, represented by Nanjing district; (c) the Buddhist music of the Western Liangzhou area, represented by Shanxi Jinyang.

Liang Wu Di of Southern Dynasties has created with “Jiangnan Wuge"(江南吴歌)， which has local music characteristics of "Shan zai" (善哉), “the Rule of Heaven” (天 道) “"the way of immortality” (仙道) and others so on a total of 10 Buddhist music. Buddhism in Northern Dynasties flourished, so its Buddhist music was very popular and profoundly influenced by the northern folk music. The flourishing of Buddhism in the Tang Dynasty continued to promote the regional differentiation and development of Buddhist music, forming a great tradition, in which the south Buddhist music was graceful or gentle and the north Buddhist music was Magnificent or profound. At the same time, Buddhist music in Tang Dynasty shaped colorful characteristics in different areas such as the style of inner and outer customs（关内关外），Wu Shu（吴蜀） and other regions. After the Song Dynasty, the collection and arrangement of folk music changed from the official to the folk. Folk music performance venues that had taken the monastery as the center in the Tang Dynasty transferred to the fixed places that were called to "Vazi" (瓦子) or "Vasi" (瓦肆) be used to perform Buddhist music in the Song Dynasty. "Vazi" (瓦 子) or "Vasi" (瓦肆) was not the special place for Buddhist activities, but it was used to play folk music places. Monasteries still have musical performances in major religious activities. Some of the larger monasteries have been 
holding theater performances and regularly held temple fairs (庙会). The monks in Song Dynasty in the northland like the tune of the northern folk music such as: Liangzhou (梁 州), Liuhanyan（柳含烟）, while the monks in the southland like the tune of the southern folk music such as:Yufu（渔父）, Yujiaao (渔家傲).

Buddhist music absorbed the poetry tune of the Tang and Song Dynasties' literature and the melody of the Yuan and Ming Dynasties' drama, such as: "the song of julingxiang" is the Song Ci (宋词), “Dielianhua” (蝶恋花), “Qing Taiping” (庆太平) is the Yuan Qu (元曲) “Daodaoling”(叨叨令). Practicing monks who distributed in the Buddhist monasteries throughout the country, constantly merged the secular folk music at the time of the spread of Buddhist doctrine.

\section{The Impromptu Characteristics of Chinese Folk Music Deeply Influenced on Buddhist Music}

The basic way of transmission of Chinese folk music or Buddhist music used the way of oral communication and inner understanding. This way led to the result that the form and content of the folk music was changeable and unstable. Music learners were more or less able to process and change the form and content of the music they had been studied. Buddhist musicians and learners continued to assimilate local music. Monks in the process of playing religious music often improvised play and field adaptation in order to adapt to local listeners. So the Buddhist music that monks played also has the extemporaneous characteristics of folk music.

\section{The Influence of Buddhist Music on CHINESE FOLK MUSIC}

Buddhist music promotes Buddhist doctrines and religious beliefs through the measure of music in order to attract the masses to believe in Buddhism. So the Buddhist music has the characteristics of religious, public and story. During the Sui Dynasty and the Tang dynasty, the monks in the monastery, who were responsible for the dissemination of Buddhist knowledge to the people, were called "teachers" (经师). They Propagated Buddh ist doctrine to the public by the way of speaking, chanting and singing. This way was called “ChangDao" (唱导). Because of “ChangDao" considerably absorbed the folk music tunes. Compared to Indian Buddhist music, it is more attractive to the public. Local folk music absorbed the religious story and learned the form of "changDao". "ChangDao" was kown as "SuJiang" (俗讲) because it is for non-monks. The law of Song Dynasty prohibited monks from "SuJiang". The "SuJiang" on the basis of the "Bianwen" (变文) that was about the story in the Buddhist scriptures (佛 经) was gradually evolved into the "Baojuan" (宝卷). "Baojuan" absorbed of Chinese folklore and developed a variety of literary genre, such as: Chinese opera (戏剧), Tanci (弹词) and Guci (鼓 词) and so on. The names of folk music in the Song Dynasty and Yuan Dynasty were able to observe the influence of Buddhist music, such as: Pusaman (菩萨蛮), double-tune of Wugongyang（双调五供养）, Puanzhou（普庵咒）. Ming and Qing Dynasties "Baojuan” was very popular in folk religion
(民间宗教) and social life. Citizens often invited monks to their home to play Buddhist music and explain Buddhist scriptures. At the same time, they would ask the monks to sing popular folk music. At that time many Buddhist music was played with folk music tunes. Ming emperor, ZhuDi (朱 棣), issued fifty volumes of Buddhist songs in 1418 and asked the monks and people in the country to learn and sing. These Buddhist songs became popular folk music at the time. The melody of the Buddhist music "Gantianren" (感天人) directly quoted the tunes of the northern folk music “Xiaoliangzhou" (小梁州) . From Ming and Qing Dynasties to modern times, Buddhist music compared with Tang and Song dynasties, was increasingly declining. On the other hand, in this decline, due to the influence of Buddhist music, folk music, especially folk instrumental music and rap music, was increasingly prosperous. Therefore, the process of Buddhist music decline can also be seen as a process of further integration with folk music.

\section{CONCLUSION}

In summary, the development of Buddhist music was a process of continuous learning and absorption of folk music. The content and form of folk music were influenced by the Buddhist music and developed more schools. It was a dynamic process between Buddhist music and folk music.

\section{REFERENCES}

[1] Yin Falu. Music Activities of Chinese Ancient Buddhist Temples, From Confucianism, Buddhism and Taoism and Traditional Culture [C]. Zhonghua Book Company.1990.

[2] Zhang Shenglu.The Relationship between Buddhist Music and Folk Buddhism in Tianjin [J].Chinese Music.1989(3).

[3] Tian Qing. On Buddhism and Chinese Music[J].Music Research.1987 (04).

[4] Wang Yafeng.Buddhist music and Chinese traditional music [N].China Ethnic News.2017-01-04.

[5] Liu Jiangping.On Chinese Buddhist music [J].Morden Music.2016(23).

[6] Zou Lingyan. On the Religious Function of Buddhist Music [J].Seeker.2006(02).

[7] Mou Zhongjian, Zhang Jian. General History of Chinese Religion [M].China Social Science Press.2014.

[8] Chen Yueqin. Buddhist Music in Tang Dynasty in China [J].Art Sea.2014(06).

[9] $\mathrm{Xu}$ Chunying.On Ancient Chinese Buddhist Music Culture [J].Buddist Music.2010(04). 